Brief Report

\title{
First Insights into the Effect of Mycorrhizae on the Expression of Pathogen Effectors during the Infection of Grapevine with Plasmopara viticola
}

\author{
Ana Cruz-Silva (D), Andreia Figueiredo *(D) and Mónica Sebastiana* \\ BioISI-Instituto de Biossistemas e Ciências Integrativas, Faculdade de Ciências, Universidade de Lisboa, \\ 1749-016 Lisboa, Portugal; fc52476@alunos.fc.ul.pt \\ * Correspondence: aafigueiredo@fc.ul.pt (A.F.); mgsebastiana@fc.ul.pt (M.S.)
}

Citation: Cruz-Silva, A.; Figueiredo, A.; Sebastiana, M. First Insights into the Effect of Mycorrhizae on the Expression of Pathogen Effectors during the Infection of Grapevine with Plasmopara viticola. Sustainability 2021, 13, 1226. https://doi.org/

$10.3390 /$ su13031226

Academic Editor: José

Manuel Mirás-Avalos

Received: 22 December 2020

Accepted: 21 January 2021

Published: 25 January 2021

Publisher's Note: MDPI stays neutral with regard to jurisdictional claims in published maps and institutional affiliations.

Copyright: (C) 2021 by the authors. Licensee MDPI, Basel, Switzerland. This article is an open access article distributed under the terms and conditions of the Creative Commons Attribution (CC BY) license (https:/ / creativecommons.org/licenses/by/ $4.0 /)$.

\begin{abstract}
Grapevine (Vitis vinifera L.), widely used for berry and wine production, is highly susceptible to the pathogenic oomycete Plasmopara viticola, the etiological agent of grapevine downy mildew disease. The method commonly used to prevent and control $P$. viticola infection relies on multiple applications of chemical fungicides. However, with European Union goals to lower the usage of such chemicals in viticulture there is a need to develop new and more sustainable strategies. The use of beneficial microorganisms with biocontrol capabilities, such as the arbuscular mycorrhizal fungi (AMF), has been pointed out as a viable alternative. With this study, we intended to investigate the effect of AMF colonization on the expression of $P$. viticola effectors during infection of grapevine. Grapevine plants were inoculated with the AMF Rhizophagus irregularis and, after mycorrhizae development, plants were infected with $P$. viticola. The expression of $P$. viticola RxLR effectors was analyzed by real-time PCR (qPCR) during the first hours of interaction. Results show that pre-mycorrhizal inoculation of grapevine alters the expression of several P. viticola effectors; namely, PvRxLR28, which presented decreased expression in mycorrhizal plants at the two time points post-infection tested. These results suggest that the pre-inoculation of grapevine with AMF could interfere with the pathogen's ability to infect grapevine by modulation of pathogenicity effectors expression, supporting the hypothesis that AMF can be used to increase plant resistance to pathogens and promote more sustainable agriculture practices, particularly in viticulture.
\end{abstract}

Keywords: mycorrhizas; arbuscular mycorrhizal fungi; Plasmopara viticola; Vitis vinifera; RxLR effectors

\section{Introduction}

During plant-pathogen interaction, several layers of defense are activated [1-3]. The first layer of plant defense consists of the recognition of Pathogen-Associated Molecular Patterns (PAMP) through Pattern Recognition Receptors (PRR) that trigger PAMP-Triggered Immunity (PTI). PTI is effective against non-adapted pathogens but not against adapted pathogens, because these are able to secrete effectors [2]. Effectors are low molecular weight proteins, secreted by pathogenic bacteria, fungi and oomycete into the plant cells, design to suppress or interfere with PTI response [4,5]. When the first layer of defense is overcome, plants activate a second layer, designed to recognize pathogen effectors. Resistance (R) proteins from the nucleotide-binding leucine-rich repeat (NB-LRR) family belong to this second layer, being able to recognize directly or indirectly pathogen effectors and activate Effector-Triggered Immunity (ETI) [2]. ETI activation may lead to hypersensitive response (HR), a programmed cell death (PCD) response caused by the plant in an attempt to control the spread of the infection. However, some of the effectors secreted by pathogens are capable of suppressing ETI also, resulting in an Effector-Triggered Susceptibility (ETS) [2].

Within plant-pathogen interactions, the grapevine downy mildew disease stands out due to the economic and social importance of grapevine. Vitis vinifera L., the cultivated Vitis specie widely used for berry and wine production, is highly susceptible to the pathogenic 
oomycete Plasmopara viticola (Berk. \& M.A. Curtis) Berl. \& De Toni the causal agent of grapevine downy mildew disease [6,7]. This pathogen was introduced in Europe in midto late-19th century together with grapevine cuttings imported from America, the endemic region of this disease [6]. P. viticola spread rapidly across the European continent and by 1915 France reported a loss of $70 \%$ of its grape production to downy mildew disease [6]. $P$. viticola is an obligatory biotrophic oomycete that infects all green parts of the grapevine plant, such as leaves, twigs or young berries [8].

In the grapevine-P. viticola interaction, it is known that $P$. viticola secrets effectors, and several potential effector genes have been identified [9-15]. Oomycete effector proteins may act either in the apoplast (apoplastic effectors) or in the cytoplasm [5]. Within the cytoplasmatic effectors, several studies highlight RxLR effectors due to their adaptative role to facilitate biotrophy [16] and to suppress PTI and/or ETI [17]. The P. viticola RxLR effectors described so far show different expression patterns throughout the infection of grapevine tissues $[10,13,18]$, many of them targeting the plant nucleus $[15,18,19]$ and acting to suppress plant immunity responses, such as the defense-related PCD, a hallmark of hypersensitive response-based immunity in plants $[10,15,18-21]$. Studies by Xiang et al. [18] suggest that $P$. viticola RxLR effectors suppress plant immunity by impairing $\mathrm{H}_{2} \mathrm{O}_{2}$ accumulation and reducing the transcriptional levels of defense-related genes, such as those involved in phytohormones essential for the immune response. Other studies on P. viticola effector function report an impairment of defense-related callose deposition and PCD at the site of infection, which were associated with effector targeting BKI1, an inhibitor of receptor-like kinases, resulting in the suppression of hormone signaling (brassinosteroid and ERECTA) involved in plant defense responses [20].

Currently, the main method to control downy mildew disease is through multiple applications of chemical fungicides, copper- and sulfur-based compounds [6]. However, the large quantities of fungicides used have led to environmental pollution, since these can accumulate in the soil and water. In 2003, Europe reported that 68 thousand tons of fungicides had been used to control grapevine diseases (Eurostat report, 2007). Therefore, the European Union has established goals to lower the usage of chemicals in viticulture (Directive 2009/128/EC) and so, there is a need to define innovative strategies to control this disease. Beneficial microorganisms with biocontrol capabilities, such as the arbuscular mycorrhizal fungi (AMF) constitute a promising way for reducing the application of fungicides [22,23].

AMF colonize about $80 \%$ of terrestrial plants, establishing a symbiotic relationship at the root level. Several studies have shown that mycorrhizal colonization leads to higher biomass and photosynthetic activity, along with alleviation of damage caused by pathogens through increased resistance of the host plant, mycorrhizal plants show a reduction in disease symptoms when compared to non-mycorrhizal plants [24-28]. The most important AMF-induced biocontrol mechanism seems to be the priming of the defense mechanisms of the host plant [22]. Priming is a phenomenon that sensitizes the plant leading to an alert state that allows a rapid and efficient defense activation when the plant is challenged by a pathogen [22]. Several studies have showed that when plants are pre-colonized by AMF, there is an induction of defense-related genes and proteins, increases in the level of defense phytohormones, antioxidant enzymes and defense compounds after pathogen attack, resulting in a better defense response when compared to non-mycorrhizal plants $[24-27,29,30]$. This mycorrhiza-induced priming effect is not restricted to the root being also systemically induced in the aerial parts of the plant when challenged with foliar pathogens $[27,28]$.

While the above-cited studies have addressed the effect of mycorrhizas on the ability of plants to mount a defense response following pathogen attack, no studies have been performed on the effect of plant symbiosis with AMF on the pathogenic organism during infection. In this preliminary study we have evaluated the effect of AMF inoculation of grapevine plants on P. viticola pathogenicity by gene expression analysis targeting eight P. viticola RxLR effector genes. Here, we present for the first time, evidence that AMF 
root colonization contributes for the modulation of $P$. viticola effector gene expression and hence AMF could be used to promote increased resistance to this pathogen, contributing to increase sustainability of agricultural practices, particularly in viticulture.

\section{Materials and Methods}

\subsection{Plant Material and AMF Inoculation}

Vitis vinifera cv Cabernet Sauvignon grapevine cuttings, grafted on Sélection Oppenheim 4 (SO4) rootstock, were obtained from the company VitiOeste (Leiria, Portugal). This grapevine cultivar (Vitis International Variety Catalogue number 1929) originated in France is highly susceptible to the pathogen P. viticola. SO4 is one of the most used rootstocks in viticulture due to its high number of roots, enabling high fruit quality and productivity. It is a hybrid between Vitis berlandieri and Vitis riparia that is able to adapt to different types of soil and environmental condition [31] being tolerant to phylloxera and nematodes [32]. A commercial inoculum of the Rhizophagus irregularis AMF was obtained from Symbiom (Lanškroun, Czech Republic). Grapevine cuttings were transferred to pots containing a sterile mix $(3: 1 v / v)$ of peat (pot plant substrate plus, Bord na Mona, $\mathrm{pH}$ 5.3-5.7) and vermiculite (grade 2 ). Inoculation with $R$. irregularis was performed by irrigation of the soil with a fungal spore suspension. Twenty-four cuttings were inoculated with $0.38 \mathrm{~g}$ of $R$. irregularis inoculum each, corresponding to approximately 1500 spores per cutting. The same number of cuttings was irrigated only with water to be used as controls. The cuttings were kept under natural conditions of light and temperature, from April to August 2019. Plants were irrigated when needed, and enough water was added to ensure that the soil was completely saturated.

\subsection{Plant Growth and Mycorrhizal Colonization}

A total of four months post AMF inoculation, the length and weight of the shoots of inoculated and non-inoculated plants was measured.

$R$. irregularis-inoculated and non-inoculated root samples were stained with trypan blue to evaluate the root colonization level of the inoculated plants. Briefly, roots from inoculated and non-inoculated plants were collected, washed, and cut into $1 \mathrm{~cm}$ segments. The segments were cleared in three different boiling $10 \% \mathrm{KOH}$ solutions in sequence, during 5, 10 and $15 \mathrm{~min}$, respectively, and then washed 4-5 times in distilled water and acidified in a $3.5 \% \mathrm{HCl}$ solution for $20 \mathrm{~min}$. Next, root segments were stained in a $0.05 \%$ Trypan blue solution $\left(\mathrm{H}_{2} \mathrm{O}\right.$ : lactic acid: glycerol; 1:1:1) for $7 \mathrm{~min}$ at an elevated temperature (without boiling). Stained root segments were washed in distilled water (4-5 times) and stored in distilled water at $4{ }^{\circ} \mathrm{C}$. Six inoculated plants and five non-inoculated plants were used for mycorrhizal assessment. 80-100 segments were observed for each plant for the presence of AMF fungal structures such as hyphae, vesicles or arbuscules using microscopes SteREO Lumar V.12 (Zeiss, Oberkochen, Germany) and Olympus BX51 (Olympus, Tokyo, Japan) for higher resolution imaging. Mycorrhizal colonization was expressed as percentage of root segments containing mycorrhizal structures (internal hyphae, vesicle or arbuscule).

\subsection{Plasmopara viticola Inoculation}

A total of four months after AMF inoculation, grapevine plants were infected with P. viticola according to procedure described by Figueiredo et al. [33]. Briefly, P. viticola was collected from symptomatic leaves of field infected plants, after an overnight incubation in a moist chamber at room temperature. Fungal sporangia were carefully collected by brushing the abaxial surfaces of symptomatic leaves and stored at $-25^{\circ} \mathrm{C}$. Prior to inoculation, sporangia viability was confirmed by microscopic observations as described in Kortekamp et al. [34]. A spore solution of $1.8 \times 10^{4} \mathrm{~mL}^{-1}$ was used to spray the abaxial leaf surface (3rd to 5 th leaves from the shoot apex) of mycorrhizal and non-mycorrhizal grapevine plants. After inoculation, plants were kept in the dark for $8 \mathrm{~h}$ in a moist chamber (100\% humidity) and then kept under greenhouse conditions during the infection time course. P. viticola inoculated leaves were collected at 6 and $24 \mathrm{~h}$ post inoculation (hpi), 
snap frozen in liquid nitrogen and stored at $-80^{\circ} \mathrm{C}$. For each treatment (mycorrhized and non-mycorrhized) and time-point (6 hpi and $24 \mathrm{hpi}$ ) leaves from 10 different plants were collected. Disease development (infection control) was assessed using eight $P$. viticola inoculated plants by observation of downy mildew typical disease symptoms, such as "oil spots" and sporulation (Figure S1 in Supplementary Materials).

\subsection{Plasmopara viticola Effector Gene Expression Analysis}

\subsubsection{RNA Extraction and cDNA Synthesis}

From each treatment (mycorrhized and non-mycorrhized) and time-point (6 hpi and $24 \mathrm{hpi}$ ), five biological replicates were used for total RNA extraction using the Spectrum ${ }^{\mathrm{TM}}$ Plant Total RNA Kit (Sigma-Aldrich, St. Louis, MO, USA) following manufacturer's instructions. Total RNA was DNase treated using the On-Column DNAse I digest set (Sigma-Aldrich, St. Louis, MO, USA). RNA concentration and purity were assessed using a NanoDrop 1000 spectrophotometer (Thermo Fisher Scientific, Waltham, MA, USA), while integrity was assessed by agarose gel electrophoresis. To detect contamination with genomic DNA (gDNA), treated RNA was used as a template for a real-time PCR (qPCR) reaction using specific primers for $V$. vinifera housekeeping gene elongation factor 1-alpha $(E F 1 \alpha)$. Primer sequences are available in Table S1.

First strand complementary DNA (cDNA) synthesis was performed as follows: $2 \mu \mathrm{g}$ of total RNA were incubated with $2.5 \mu \mathrm{M}$ oligo d(T) primer at $70{ }^{\circ} \mathrm{C}$ for $10 \mathrm{~min}$ in a final volume of $20 \mu \mathrm{L}$. Next, $1 \mathrm{X}$ RT buffer, $1 \mathrm{mM}$ of dNTP and $1 \mathrm{U} / \mu \mathrm{L}$ of Ribolock RNase Inhibitor were added, and the mixture was incubated $5 \mathrm{~min}$ at $37^{\circ} \mathrm{C}$. Five $\mathrm{U}$ of RevertAid $\mathrm{H}$ Minus Reverse Transcriptase were added and the samples were incubated at $42{ }^{\circ} \mathrm{C}$ during $90 \mathrm{~min}$. The reaction was stopped by a $10 \mathrm{~min}$ incubation at $70^{\circ} \mathrm{C}$. All reaction components were from Thermo Fisher Scientific (Waltham, MA, USA). cDNA was stored at $-20^{\circ} \mathrm{C}$.

\subsection{2. qPCR Gene Expression Analysis}

Specific primers for the amplification of selected P. viticola RxLR effectors and reference genes ( $P$. viticola actin and $\beta$-tubulin) were design using the software's PrimerSelect (DNA Star Package, Madison, WI, USA) and PrimerBlast tool (NCBI) (Table S1). The effectors gene sequences were previously identified and studied by Mestre et al. [9] (PvRxLR18), Xiang et al. [18] (PvRxLR16, PvRxLR22, PvRxLR27, PvRxLR28, PvRxLR61 and PvRxLR67) and Chen et al. [15] (PvAVH52). Accession numbers (Acc) of each sequence are shown in Table S1.

For each biological replicate two technical replicates were performed. Each qPCR reaction (with a $25 \mu \mathrm{L}$ final volume) was composed of $2 \mu \mathrm{L}$ of 1:5 diluted cDNA, $0.2 \mathrm{mM}$ of primer reverse, $0.2 \mathrm{mM}$ of primer forward, 1X of Maxima SYBR Green/Rox qPCR MasterMix (Thermo Fisher Scientific, Waltham, MA, USA) and $\mathrm{H}_{2} \mathrm{O}$. qPCR reactions were performed in a StepOne ${ }^{\mathrm{TM}}$ Real-Time PCR system (Applied Biosystems, Sourceforge, Waltham, MA, USA). The conditions of the qPCR reaction started with an initial denaturation at $95^{\circ} \mathrm{C}$ during $10 \mathrm{~min}$, followed by 45 cycles of a $15 \mathrm{~s}$ denaturation at $95^{\circ} \mathrm{C}$ and a $30 \mathrm{~s}$ annealing reaction at a specific temperature to each primer pair (Table S1). The melting curve of each reaction was analyzed to guaranty single product amplification (Figure S2). Gene expression values were calculated as fold changes between mycorrhizal and nonmycorrhizal plants, as described in Hellemans et al. [35]. The P. viticola housekeeping genes actin and $\beta$-tubulin were used to normalize gene expression.

\subsection{Statistical Analyses}

The statistical analyses were performed using IBM SPSS statistics software (version 26.0; SPSS Inc., Chicago, IL, USA). The R. irregularis colonization rate and the plant biomass data were analyzed for normality by the Kolmogorov-Smirnov test and for equal variances with Levene's test. Differences between mycorrhizal and non-mycorrhizal plants were analyzed by independent sample $t$-test at a significance of $p<0.05$. The gene expression data was analyzed by independent samples Mann-Whitney $U$ test at a significance of $p<0.05$. 


\section{Results and Discussion}

\subsection{Mycorrhizal Colonization}

Microscopic analysis after trypan blue staining confirmed grapevine mycorrhizal root colonization by the AMF R. irregularis. The typical AM fungal structures such as hyphae, vesicles and arbuscules were clearly observed in the inoculated roots (Figure 1). The colonization rate of inoculated plants $(10 \%)$ was significantly higher when compared to the non-inoculated plants (2\%) (Figure 2). Other studies that assess AMF colonization rate of $\mathrm{SO} 4$ rootstock refer to higher colonization rates [36-38]. Even with 10\% colonization rate, grapevine plants still benefited from the AMF inoculation as plant biomass was significantly higher in R. irregularis inoculated plants. The $2 \%$ AMF colonization detected in the noninoculated plants is probably related to the fact that some of the cuttings presented already some root development. The few developed roots may have been colonized by AMF fungi, a common phenomenon in nurseries and already reported in other studies [39].

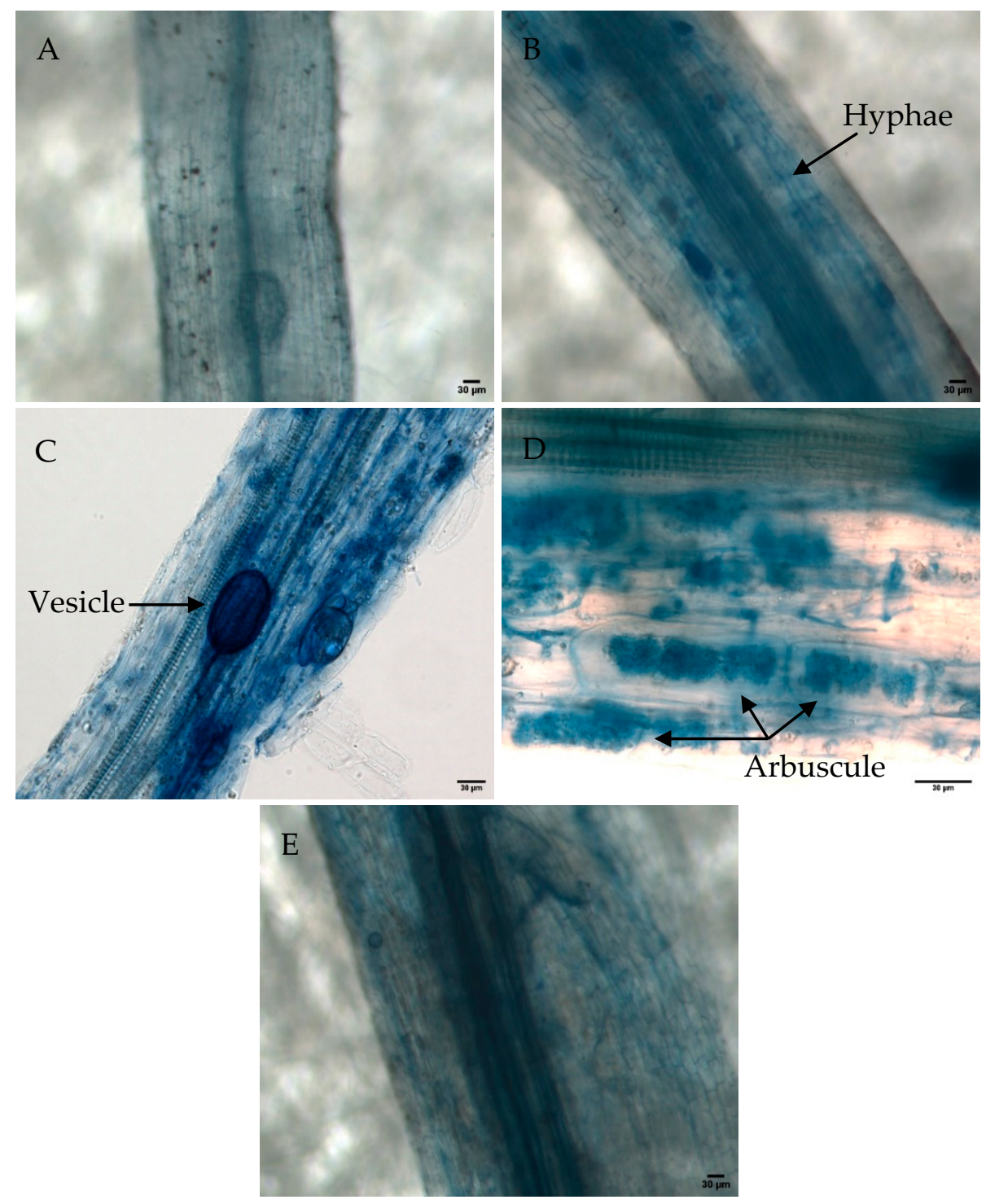

Figure 1. Mycorrhizal structures observed in grapevine roots, 6 months after $R$. irregularis inoculation (Trypan blue staining). (A) Non-colonized root segment. (B) Colonized root with AMF hyphae. (C) Colonized root with AMF vesicle. (D) Colonized root with AMF arbuscules. (E) AMF root colonization on non-inoculated roots. Scale bar: $30 \mu \mathrm{m}$. 


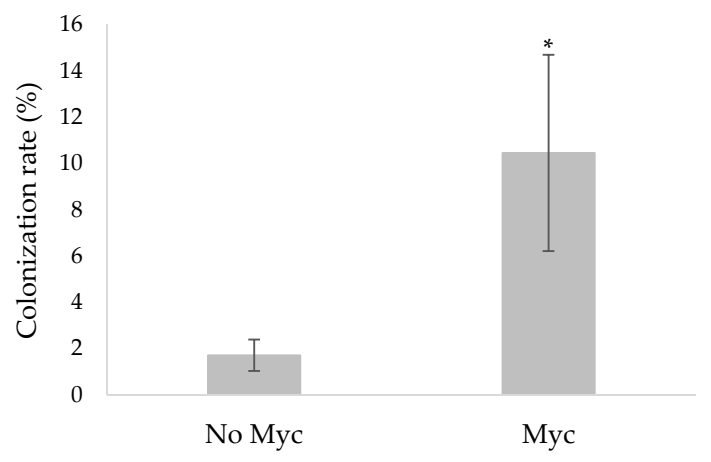

Figure 2. Colonization rate of mycorrhizal (Myc) and non-mycorrhizal (No Myc) grapevine plants 6 months after inoculation with $R$. irregularis. Statistical significance is represented by $\left(^{*}\right)(t$-test $p<0.05)$.

\subsection{Plant Biomass}

To evaluate the effect of AMF inoculation on grapevine growth, the shoot length and weight of mycorrhizal and non-mycorrhizal plants were recorded, four months postinoculation with $R$. irregularis. Results show that mycorrhizal inoculation significantly increased the biomass of the grapevine plants (Figure 3). Mycorrhizal plants showed a significantly higher shoot length $(94.57 \pm 23.40 \mathrm{~cm})$ when compared to the non-mycorrhizal plants $(74.26 \pm 15.12 \mathrm{~cm})$. Additionally, the shoot weight of the mycorrhizal plants $(39.33 \pm 7.94 \mathrm{~g})$ was significantly higher, when compared to the non-mycorrhizal plants $(24.19 \pm 5.95 \mathrm{~g})$. Mycorrhizal fungi are able to increase plant biomass by increasing the uptake of nutrients and water, as well as by reducing the effects of environmental stress in plants [40]. The small diameter of fungal hyphae allows AMF to reach pores in the soil that the plant's roots are not able to, covering large distances away from the root nutrient depletion zone [40]. An enhanced nutrient and water uptake lead to an increase in photosynthate production or hormonal balance resulting in an increased plant biomass. Several studies have reported an increase in grapevine plant growth upon AMF colonization [36,37,41-44]. Our results agree with the results from these studies and further confirm the benefits of AMF inoculation on the growth of grapevine plants.

\section{A}

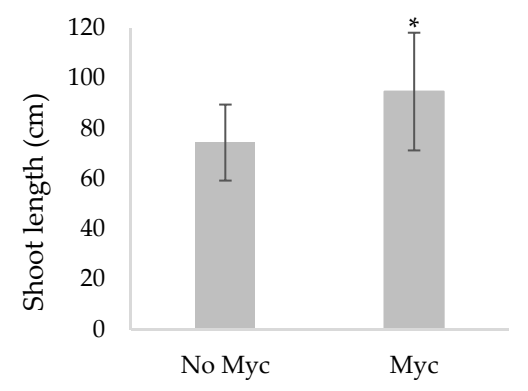

B

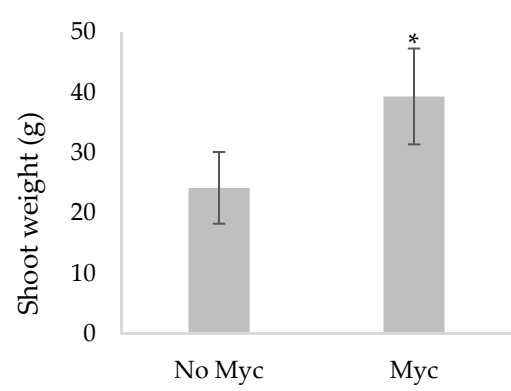

Figure 3. Effect of mycorrhizal inoculation on grapevine shoot growth. (A) Shoot length of mycorrhizal (Myc) and non-mycorrhizal plants (No Myc). (B) Shoot weight of mycorrhizal (Myc) and non-mycorrhizal plants (No Myc). Statistical significance is represented by $\left(^{*}\right)(t$-test $p<0.05)$. 


\subsection{Plasmopara viticola Effector Expression Is Altered in Mycorrhizal Grapevine Plants}

This study aimed to investigate if grapevine mycorrhizal root colonization could interfere with the expression of $P$. viticola RxLR effector molecules. We analyzed the expression profile of eight $P$. viticola effector genes selected based on previous studies that showed high expression at early infection time-points and based on their capacity to interfere with plant defenses $[9,10,15,18,45]$. Expression was analyzed in both mycorrhizal and non-mycorrhizal (control) grapevine plants infected (6 and $24 \mathrm{hpi}$ ) with the oomycete P. viticola.

From the eight RxLR effectors analyzed, four presented no expression or very low transcript abundance in both mycorrhizal and non-mycorrhizal infected plants (PvRxLR16, $P v R x L R 22, P v R x L R 27$ and PvRxLR61). In previous studies, these effectors reported to be expressed in the first $24 \mathrm{~h}$ upon infection $[10,18]$. Therefore, the lack of expression of these effectors in our study may be related to the detection limits within our experimental conditions being insufficient to detect low abundance genes. In a previous report by Gómez-Zeledón and Spring [45], these effectors were expressed at a lower level compared to other effectors in the study.

A total of four effector genes, PvRxLR18, PvAVH52, PvRxLR28 and PvRxLR67, exhibited changes of expression in mycorrhizal plants when compared with non-mycorrhizal plants upon infection with P. viticola (Figure 4). These results show for the first time that pathogen effector gene expression may be altered by plant mycorrhization. Effector PvRxLR18 showed a significant expression increase in mycorrhizal plants at 6 hpi ( $2.15 \pm 0.11$-fold change), while at 24 hpi this effector was still up-regulated but the difference between mycorrhizal and non-mycorrhizal plants was not significant. This effector was studied in infected detached leaves of $V$. vinifera $\mathrm{cv}$. Muscat Ottonel, where expression was detected early at $6 \mathrm{hpi}$, with peaks of expression reported at $24 \mathrm{hpi}$ and $48 \mathrm{hpi}$ [9]. A high PvRxLR18 expression was also detected at $12 \mathrm{hpi}$ and $48 \mathrm{hpi}$ in inoculated detached $V$. vinifera cv. Cabernet Sauvignon leaves [10]. An early induction of PvRxLR18 at $6 \mathrm{hpi}$ was reported in two grapevine cultivars, one susceptible (Müller-Thurgau) and another tolerant (Regent) to P. viticola infection [45]. Like PvRxLR18, the expression of effector PvAVH52 was also up-regulated by mycorrhizal inoculation on grapevine plants, with a significant increase at $24 \mathrm{hpi}(2.54 \pm 0.40$-fold change). This effector was reported to have a bimodal pattern of expression (increased expression at $6 \mathrm{hpi}$, that lowers at $12 \mathrm{hpi}$ and is higher again at $24 \mathrm{hpi}$ ), being also expressed later $72 \mathrm{hpi}$ [15].

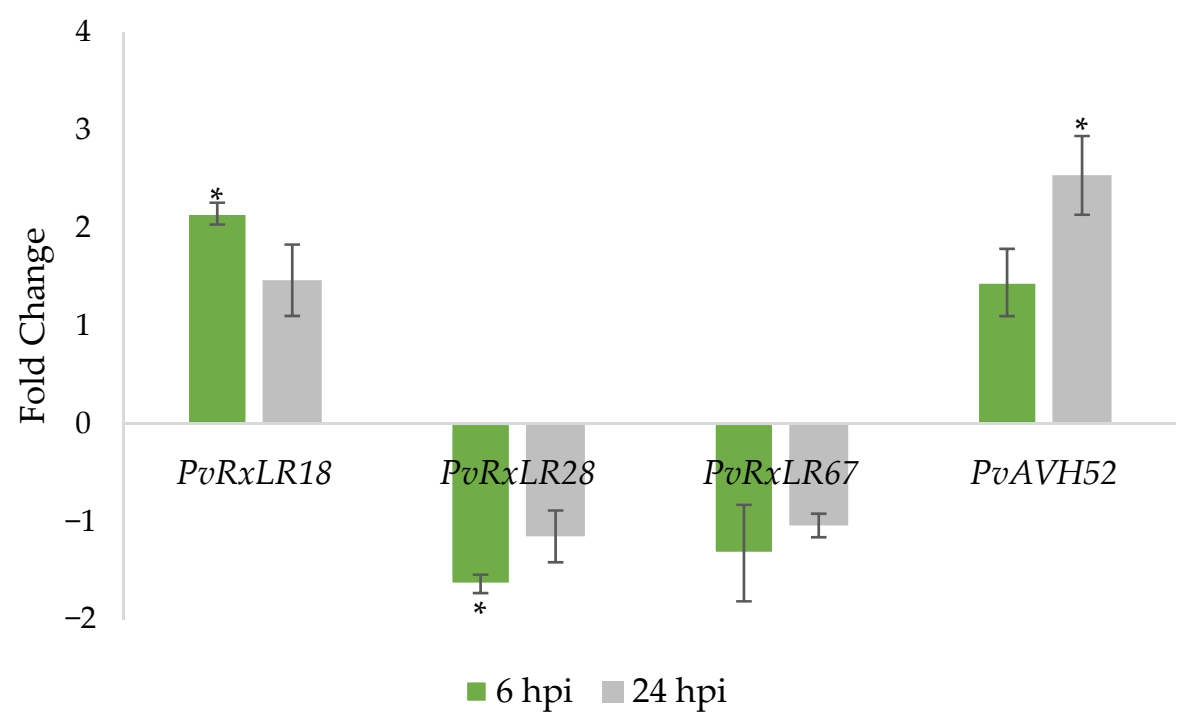

Figure 4. Effect of mycorrhizal colonization on P. viticola RxLR effector gene expression on grapevine leaves, $6 \mathrm{hpi}$ and $24 \mathrm{hpi}$. Statistical significance from comparing the expression of each effector on mycorrhizal and non-mycorrhizal plants, in each the time point, is represented by $\left(^{*}\right)(p<0.05)$. 
Studies have suggested that $P v R x L R 18$ and PvAVH52 have a role in pathogen virulence. PvAVH52 was shown to be located at the plant nucleoplasm being able to suppress PCD in Nicotiana benthamiana [15]. Although the function of effector PvRxLR18 is not yet known, its early time of expression (6 hpi) may be an indicator of its importance for the infection establishment. The increased expression of these $P$. viticola effectors genes in the mycorrhizal grapevine plants suggests that mycorrhization was able to enhance the plant defense system, and that in response the pathogen could be trying to overcome plant defense mechanism by increasing effector gene expression. Gómez-Zeledón and Spring [45] reported that when P. viticola infects a tolerant grapevine cultivar, the expression of PvRxLR18 was higher than that observed in a susceptible cultivar. Overall, the increased expression of these effectors in the mycorrhizal grapevine plants might indicate that the pathogen perceives the mycorrhizal grapevine as more tolerant, when in fact the plant used in our work is a susceptible cultivar.

In contrast, the expression of effector genes PvRxLR67 and PvRxLR28 was decreased in the mycorrhizal grapevine plants at both time points post-infection with P. viticola (Figure 4). Effector PvRxLR67 was down-regulated in infected mycorrhizal grapevine leaves at both time-points post-infection, but the decrease in expression was not significative when compared to the non-mycorrhizal plants. This effector has been reported to be expressed at $24 \mathrm{~h}$ post infection [45], however Xiang et al. [18] reported a later expression, beginning at $72 \mathrm{hpi}$ with a peak of expression at $96 \mathrm{hpi}$. Effector PvRxLR28 was significantly down-regulated at 6 hpi (-1.64 \pm 0.09 -fold change) in mycorrhizal grapevine plants when compared to nonmycorrhizal plants. This effector was also down-regulated at $24 \mathrm{hpi}$ in mycorrhizal plants but the difference between mycorrhizal and non-mycorrhizal plants was not significant. Effector PvRxLR28 was reported to be activated early during P. viticola infection process, showing a strong expression at $6 \mathrm{~h}$ post grapevine infection $[18,45]$. The inhibition of $P$. viticola effector gene expression detected in grapevine mycorrhizal plants in our study might suggest that AMF colonization results in the activation (priming) of defense mechanisms in the susceptible cultivar Cabernet Sauvignon, that could decrease pathogenicity in the first hours of infection, since this effector has been reported to interfere with plant's defense system [18]. For instance, effector PvRxLR28 enhanced tobacco susceptibility to Phytophthora parasitica infection by repressing plant defense-related genes, such as the salicylic acid responsive pathogenesis-related genes $P R 1$ and $P R 2$, the jasmonic acid responsive gene LOX and the ethylene responsive gene EFR1 [18]. Expression of this effector was able to compromise plant defenses, such as the typical $\mathrm{H}_{2} \mathrm{O}_{2}$ accumulation in infected tissues by down-regulating plant genes encoding reactive oxygen species (ROS)-producing enzymes (RbohA and RbohB) [18]. Effector PvRxLR28 was also shown to have the highest expression level, showing four times more expression when compared to other effectors studied during the course of grapevine infection [18]. The high and early expression of this effector may be essential for $P$. viticola infection progress or even to make the infection possible. The decreased expression of $P v R x R 28$ effector detected in the mycorrhizal grapevines may be of great importance to the plant since less effector expression may result in less susceptibility to the pathogen. Overall, our results strongly suggest that the mycorrhizal-induced resistance can affect $P$. viticola pathogenicity by interfering with pathogenicity effectors expression.

Previous studies have reported variations in the expression of pathogen virulence genes when colonizing resistant and susceptible cultivars in several plant species. Pathogens presented lower expression of virulence genes (some of which were effector genes) in resistant plants, suggesting a natural capacity of resistant cultivars to recognize and interfere with the expression of pathogen effectors [46-48]. In cotton plants, a defense strategy that is able to interfere with pathogen gene expression was recently identified, reinforcing the idea that plants are able to interfere with pathogen effector expression [49]. In that study, a pair of microRNAs was identified that was able to silence specific genes essential to the fungal pathogen microsclerotium formation (critical for infection) and hyphal growth, 
lowering its virulence [49]. These miRNAs are produced by the host plant after Verticillium dahliae infection and are exported to the fungal hyphae.

Regarding the effects of mycorrhizal colonization on pathogen gene expression and consequent mechanism underlying it, up to our knowledge, no studies were published so far. However, several mechanisms underlying the priming of the defense system observed in mycorrhizal plants that may be responsible for the alteration in the pathogen effector expression observed in our study, have been reported. One such mechanism is the activation of metabolic pathways that lead to the production of defense-related hormones, such as jasmonic-acid (JA) [25,50,51]. Studies also reported a higher expression of pathogenesis-related (PR) proteins when pre-mycorrhized plants are infected with pathogens $[24,25,29,50]$. An increased callose accumulation in mycorrhizal plants was also reported in leaves upon infection with pathogens [30,52]. In grapevine plants, premycorrhizal inoculation with $R$. irregularis induced the expression of genes involved in stilbenoid biosynthesis, resulting in higher levels of stilbenoid compounds in leaves in response to downy mildew and grey mold infection [26]. Interestingly, susceptible grapevine cultivars were able to produce the more toxic stilbenoid compounds viniferin and pterostilbene, only when colonized by AMF, highlighting the effectiveness of AMF colonization for inducing defense compounds in such susceptible genotypes [26].

\section{Conclusions}

This preliminary study shows that pre-mycorrhizal colonization of grapevine plants with the AMF R. irregularis interferes with the expression of some pathogenic effectors during leaf infection with P. viticola. Mycorrhizal grapevine plants inoculated with P. viticola showed a decreased expression of the effector PvRxL28, which is described to be highly expressed at early stages of infection and is able to suppress plants defenses [18]. Therefore, inhibition of this effector in mycorrhizal grapevine plants may contribute to decrease $P$. viticola pathogenicity. These results suggest that pre-mycorrhization of grapevine plants may be of importance to decrease the pathogenicity of $P$. viticola and limit its ability to infect grapevine leaves. Further studies have to be conducted to test this hypothesis, namely through the evaluation of AMF priming effects in grapevine; however, these first results are promising and further support the use of mycorrhizal fungi as an alternative for a more sustainable control of the downy mildew disease in viticulture.

Supplementary Materials: The following are available online at https:/ / www.mdpi.com/2071-105 0/13/3/1226/s1, Figure S1. Symptoms of P. viticola infection on grapevine leaves, Figure S2. Melting curves of target genes and housekeeping genes, Table S1. Genes, primers and amplification data for the qPCR analysis.

Author Contributions: Conceptualization: A.F. and M.S.; Experiments: A.F., M.S. and A.C.-S.; evaluation of mycorrhizal plants: A.C.-S. and M.S.; qPCR analysis: A.C.-S. and A.F.; manuscript writing: A.C.-S., A.F. and M.S.; supervision: A.F. and M.S. All authors have read and agreed to the published version of the manuscript.

Funding: This study was supported by Portuguese national funds through FCT—Fundação para a Ciência e a Tecnologia, I.P., in the context of Norma Transitória—DL57/2016/CP[12345/2018]/CT[2475] to MS and Investigator FCT contract IF/00819/2015 to AF. The present work was supported by PTDC/BIA-BQM/28539/2017, UIDB/04046/2020 and UIDP/04046/2020 Centre grants from FCT, Portugal (to BioISI).

Institutional Review Board Statement: Not applicable.

Informed Consent Statement: Not applicable.

Data Availability Statement: Not applicable.

Acknowledgments: The authors kindly acknowledge Marisa Maia for the preparation of $P$. viticola inoculum.

Conflicts of Interest: The authors declare no conflict of interest. 


\section{References}

1. Ingle, R.A.; Carstens, M.; Denby, K. PAMP recognition and the plant-pathogen arms race. Bioessays 2006, 28, 880-889. [CrossRef]

2. Jones, J.D.G.; Dangl, J.L. The plant immune system. Nat. Cell Biol. 2006, 444, 323-329. [CrossRef] [PubMed]

3. Hein, I.; Gilroy, E.M.; Armstrong, M.R.; Birch, P.R. The zig-zag-zig in oomycete-plant interactions. Mol. Plant Pathol. 2009, 10, 547-562. [CrossRef] [PubMed]

4. De Jonge, R.; Bolton, M.D.; Thomma, B.P.H.J. How filamentous pathogens co-opt plants: The ins and outs of fungal effectors. Curr. Opin. Plant Biol. 2011, 14, 400-406. [CrossRef] [PubMed]

5. Schornack, S.; Huitema, E.; Cano, L.M.; Bozkurt, T.O.; Oliva, R.; Van Damme, M.; Schwizer, S.; Raffaele, S.; Chaparro-Garcia, A.; Farrer, R.; et al. Ten things to know about oomycete effectors. Mol. Plant Pathol. 2009, 10, 795-803. [CrossRef]

6. Gessler, C.; Pertot, I.; Perazzolli, M. Plasmopara viticola: A review of knowledge on downy mildew of grapevine and effective disease management. Phytopathol. Mediterr. 2011, 50, 3-44.

7. Earmijo, G.; Eschlechter, R.; Eagurto, M.; Emuñoz, D.; Enúñez, C.; Arce-Johnson, P. Grapevine pathogenic microorganisms: Understanding infection strategies and host response scenarios. Front. Plant Sci. 2016, 7, 382. [CrossRef]

8. Nascimento, R.; Maia, M.; Ferreira, A.E.; Silva, A.B.; Freire, A.P.; Cordeiro, C.; Silva, M.S.; Figueiredo, A. Early stage metabolic events associated with the establishment of Vitis vinifera-Plasmopara viticola compatible interaction. Plant Physiol. Biochem. 2019, 137, 1-13. [CrossRef]

9. Mestre, P.; Piron, M.-C.; Merdinoglu, D. Identification of effector genes from the phytopathogenic Oomycete Plasmopara viticola through the analysis of gene expression in germinated zoospores. Fungal Biol. 2012, 116, 825-835. [CrossRef] [PubMed]

10. Yin, L.; Li, X.; Xiang, J.; Qu, J.; Zhang, Y.; Dry, I.B.; Lu, J. Characterization of the secretome of Plasmopara viticola by de novo transcriptome analysis. Physiol. Mol. Plant Pathol. 2015, 91, 1-10. [CrossRef]

11. Mestre, P.; Carrere, S.; Gouzy, J.; Piron, M.-C.; De Labrouhe, D.T.; Vincourt, P.; Delmotte, F.; Godiard, L. Comparative analysis of expressed CRN and RXLR effectors from two Plasmopara species causing grapevine and sunflower downy mildew. Plant Pathol. 2016, 65, 767-781. [CrossRef]

12. Yin, L.; An, Y.; Qu, J.; Li, X.; Zhang, Y.; Dry, I.; Wu, H.; Lu, J. Genome sequence of Plasmopara viticola and insight into the pathogenic mechanism. Sci. Rep. 2017, 7, 46553. [CrossRef] [PubMed]

13. Brilli, M.; Asquini, E.; Moser, M.; Bianchedi, P.L.; Perazzolli, M.; Si-Ammour, A. A multi-omics study of the grapevine-downy mildew (Plasmopara viticola) pathosystem unveils a complex protein coding- and noncoding-based arms race during infection. Sci. Rep. 2018, 8, 757. [CrossRef] [PubMed]

14. Dussert, Y.; Mazet, I.D.; Couture, C.; Gouzy, J.; Piron, M.-C.; Kuchly, C.; Bouchez, O.; Rispe, C.; Mestre, P.; Delmotte, F. A high-quality grapevine downy mildew genome assembly reveals rapidly evolving and lineage-specific putative host adaptation genes. Genome Biol. Evol. 2019, 11, 954-969. [CrossRef]

15. Chen, T.; Liu, R.; Dou, M.; Li, M.; Li, M.; Yin, X.; Liu, G.-T.; Wang, Y.; Xu, Y. Insight into function and subcellular localization of Plasmopara viticola putative RXLR effectors. Front. Microbiol. 2020, 11, 692. [CrossRef]

16. Whisson, S.C.; Boevink, P.C.; Moleleki, L.; Avrova, A.O.; Morales, J.G.; Gilroy, E.M.; Armstrong, M.R.; Grouffaud, S.; Van West, P.; Chapman, S.; et al. A translocation signal for delivery of oomycete effector proteins into host plant cells. Nat. Cell Biol. 2007, 450, 115-118. [CrossRef]

17. Anderson, R.G.; Casady, M.S.; Fee, R.A.; Vaughan, M.M.; Deb, D.; Fedkenheuer, K.; Huffaker, A.; Schmelz, E.A.; Tyler, B.M.; McDowell, J. Homologous RXLR effectors from Hyaloperonospora arabidopsidis and Phytophthora sojaesuppress immunity in distantly related plants. Plant J. 2012, 72, 882-893. [CrossRef]

18. Xiang, J.; Li, X.; Wu, J.; Yin, L.; Zhang, Y.; Lu, J. Studying the mechanism of Plasmopara viticola RXLR effectors on suppressing plant immunity. Front. Microbiol. 2016, 7, 709. [CrossRef]

19. Liu, Y.; Lan, X.; Song, S.; Yin, L.; Dry, I.B.; Qu, J.; Xiang, J.; Lu, J. In planta functional analysis and subcellular localization of the oomycete pathogen Plasmopara viticola candidate RXLR effector repertoire. Front. Plant Sci. 2018, 9, 286. [CrossRef]

20. Lan, X.; Liu, Y.; Song, S.; Yin, L.; Xiang, J.; Qu, J.; Lu, J. Plasmopara viticola effector PvRXLR131 suppresses plant immunity by targeting plant receptor-like kinase inhibitor BKI1. Mol. Plant Pathol. 2019, 20, 765-783. [CrossRef]

21. Lei, X.; Lan, X.; Ye, W.; Liu, Y.; Song, S.; Lu, J. Plasmopara viticola effector PvRXLR159 suppresses immune responses in Nicotiana benthamiana. Plant Signal. Behav. 2019, 14, 1682220. [CrossRef] [PubMed]

22. Pozo, M.J.; Verhage, A.; García-Andrade, J.; García, J.M.; Azcón-Aguilar, C. Priming plant defence against pathogens by arbuscular mycorrhizal fungi. In Mycorrhizas-Functional Processes and Ecological Impact; Azcón-Aguilar, C., Barea, J.M., Gianinazzi, S., Gianinazzi-Pearson, V., Eds.; Springer: Berlin/Heidelberg, Germany, 2009; pp. 123-135. ISBN 978-3-540-87977-0.

23. Singh, I.; Giri, B. Arbuscular mycorrhiza mediated control of plant pathogens. In Mycorrhiza-Nutrient Uptake, Biocontrol, Ecorestoration; Varma, A., Prasad, R., Tuteja, N., Eds.; Springer International Publishing: Cham, Switzerland, 2017; pp. 131-160. ISBN 978-3-319-68866-4.

24. Campos-Soriano, L.; García-Martínez, J.; Segundo, B.S. The arbuscular mycorrhizal symbiosis promotes the systemic induction of regulatory defence-related genes in rice leaves and confers resistance to pathogen infection. Mol. Plant Pathol. 2011, 13, 579-592. [CrossRef] [PubMed]

25. Song, Y.; Chen, D.; Lu, K.; Sun, Z.; Zeng, R. Enhanced tomato disease resistance primed by arbuscular mycorrhizal fungus. Front. Plant Sci. 2015, 6, 786. [CrossRef] 
26. Bruisson, S.; Maillot, P.; Schellenbaum, P.; Walter, B.; Gindro, K.; Deglène-Benbrahim, L. Arbuscular mycorrhizal symbiosis stimulates key genes of the phenylpropanoid biosynthesis and stilbenoid production in grapevine leaves in response to downy mildew and grey mould infection. Phytochemistry 2016, 131, 92-99. [CrossRef] [PubMed]

27. Wang, Y.-Y.; Yin, Q.-S.; Qu, Y.; Li, G.-Z.; Hao, L. Arbuscular mycorrhiza-mediated resistance in tomato against Cladosporium fulvum-induced mould disease. J. Phytopathol. 2018, 166, 67-74. [CrossRef]

28. Fiorilli, V.; Vannini, C.; Ortolani, F.; Garcia-Seco, D.; Chiapello, M.; Novero, M.; Domingo, G.; Terzi, V.; Morcia, C.; Bagnaresi, P.; et al. Omics approaches revealed how arbuscular mycorrhizal symbiosis enhances yield and resistance to leaf pathogen in wheat. Sci. Rep. 2018, 8, 1-18. [CrossRef] [PubMed]

29. Gallou, A.; Mosquera, H.P.L.; Cranenbrouck, S.; Suárez, J.P.; Declerck, S. Mycorrhiza induced resistance in potato plantlets challenged by Phytophthora infestans. Physiol. Mol. Plant Pathol. 2011, 76, 20-26. [CrossRef]

30. Sanmartín, N.; Pastor, V.; Pastor-Fernández, J.; Flors, V.; Pozo, M.J.; Sánchez-Bel, P. Role and mechanisms of callose priming in mycorrhiza-induced resistance. J. Exp. Bot. 2020, 71, 2769-2781. [CrossRef]

31. Reynier, A. Manual de Viticultura, 6th ed.; Mundi Prensa: Madrid, Spain, 2002.

32. McKenry, M.; Anwar, S.A. Nematode and grape rootstock interactions including an improved understanding of tolerance. J. Nematol. 2006, 38, 312-318.

33. Figueiredo, A.; Monteiro, F.; Fortes, A.M.; Bonow-Rex, M.; Zyprian, E.; Sousa, L.; Pais, M.S. Cultivar-specific kinetics of gene induction during downy mildew early infection in grapevine. Funct. Integr. Genom. 2012, 12, 379-386. [CrossRef]

34. Kortekamp, A.; Welter, L.; Vogt, S.; Knoll, A.; Schwander, F.; Töpfer, R.; Zyprian, E. Identification, isolation and characterization of a CC-NBS-LRR candidate disease resistance gene family in grapevine. Mol. Breed. 2008, 22, 421-432. [CrossRef]

35. Hellemans, J.; Mortier, G.R.; De Paepe, A.; Speleman, F.; Vandesompele, J. qBase relative quantification framework and software for management and automated analysis of real-time quantitative PCR data. Genome Biol. 2007, 8, R19. [CrossRef] [PubMed]

36. Hao, Z.; Fayolle, L.; Van Tuinen, D.; Chatagnier, O.; Li, X.; Gianinazzi, S.; Gianinazzi-Pearson, V. Local and systemic mycorrhizainduced protection against the ectoparasitic nematode Xiphinema index involves priming of defence gene responses in grapevine. J. Exp. Bot. 2012, 63, 3657-3672. [CrossRef] [PubMed]

37. Cangahuala-Inocente, G.C.; Da Silva, M.F.; Johnson, J.-M.; Manga, A.; Van Tuinen, D.; Henry, C.; Lovato, P.E.; Dumas-Gaudot, E. Arbuscular mycorrhizal symbiosis elicits proteome responses opposite of P-starvation in SO4 grapevine rootstock upon root colonisation with two Glomus species. Mycorrhiza 2011, 21, 473-493. [CrossRef] [PubMed]

38. Massa, N.; Bona, E.; Novello, G.; Todeschini, V.; Boatti, L.; Mignone, F.; Gamalero, E.; Lingua, G.; Berta, G.; Cesaro, P. AMF communities associated to Vitis vinifera in an Italian vineyard subjected to integrated pest management at two different phenological stages. Sci. Rep. 2020, 10, 1-12. [CrossRef]

39. Nogales, A.; Santos, E.S.; Abreu, M.M.; Arán, D.; Victorino, G.; Pereira, H.S.; Lopes, C.M.; Viegas, W. Mycorrhizal inoculation differentially affects grapevine's performance in copper contaminated and non-contaminated soils. Front. Plant Sci. 2019, 9. [CrossRef]

40. Smith, S.E.; Read, D. Preface. In Mycorrhizal Symbiosis; Academic Press: Cambridge, MA, USA, 2008; pp. vii-ix. ISBN 9780123705266.

41. Velásquez, A.; Vega-Celedón, P.; Fiaschi, G.; Agnolucci, M.; Avio, L.; Giovannetti, M.; D’Onofrio, C.; Seeger, M. Responses of Vitis vinifera cv. Cabernet Sauvignon roots to the arbuscular mycorrhizal fungus Funneliformis mosseae and the plant growth-promoting rhizobacterium Ensifer meliloti include changes in volatile organic compounds. Mycorrhiza 2020, 30, 161-170. [CrossRef]

42. Linderman, R.G.; Davis, E.A. Comparative response of selected grapevine rootstocks and cultivars to inoculation with different mycorrhizal fungi. Am. J. Enol. Vitic. 2001, 52, 8.

43. Nikolaou, N.; Angelopoulos, K.; Karagiannidis, N. Effects of drought stress on mycorrhizal and non-mycorrhizal cabernet sauvignon grapevine, grafted onto various rootstocks. Exp. Agric. 2003, 39, 241-252. [CrossRef]

44. Ozdemir, G.; Akpinar, C.; Sabir, A.; Bilir, H.; Tangolar, S.; Ortas, I. Effect of inoculation with mycorrhizal fungi on growth and nutrient uptake of grapevine genotypes (Vitis Spp.). Europ. J. Hort. Sci. 2010, 75, 8.

45. Gómez-Zeledón, J.; Spring, O. Up-regulated RxLR effector genes of Plasmopara viticola in synchronized host-free stages and infected leaves of hosts with different susceptibility. Fungal Biol. 2018, 122, 1125-1133. [CrossRef] [PubMed]

46. Thatcher, L.F.; Williams, A.H.; Garg, G.; Buck, S.-A.G.; Singh, K.B. Transcriptome analysis of the fungal pathogen Fusarium oxysporum $\mathrm{f}$. sp. medicaginis during colonisation of resistant and susceptible Medicago truncatula hosts identifies differential pathogenicity profiles and novel candidate effectors. BMC Genom. 2016, 17, 1-19. [CrossRef]

47. Ding, Y.; Mei, J.; Chai, Y.; Yu, Y.; Shao, C.; Wu, Q.; Disi, J.O.; Li, Y.; Wan, H.; Qian, W. Simultaneous transcriptome analysis of host and pathogen highlights the interaction between Brassica oleracea and Sclerotinia sclerotiorum. Phytopathology 2019, 109, 542-550. [CrossRef] [PubMed]

48. Kandel, S.L.; Hulse-Kemp, A.M.; Stoffel, K.; Koike, S.T.; Shi, A.; Mou, B.; Van Deynze, A.; Klosterman, S.J. Transcriptional analyses of differential cultivars during resistant and susceptible interactions with Peronospora effusa, the causal agent of spinach downy mildew. Sci. Rep. 2020, 10, 1-13. [CrossRef]

49. Zhang, T.; Zhao, Y.-L.; Zhao, J.-H.; Wang, S.; Jin, Y.; Chen, Z.-Q.; Fang, Y.-Y.; Hua, C.; Ding, S.-W.; Guo, H.-S. Cotton plants export microRNAs to inhibit virulence gene expression in a fungal pathogen. Nat. Plants 2016, 2, 16153. [CrossRef] [PubMed]

50. Zhang, Q.; Gao, X.; Ren, Y.; Ding, X.; Qiu, J.; Li, N.; Zeng, F.; Chu, Z. Improvement of verticillium wilt resistance by applying arbuscular mycorrhizal fungi to a cotton variety with high symbiotic efficiency under field conditions. Int. J. Mol. Sci. 2018, 19, 241. [CrossRef] 
51. Sanmartín, N.; Sánchez-Bel, P.; Pastor, V.; Pastor-Fernández, J.; Mateu, D.; Pozo, M.J.; Cerezo, M.; Flors, V. Root-to-shoot signalling in mycorrhizal tomato plants upon Botrytis cinerea infection. Plant Sci. 2020, 298, 110595. [CrossRef]

52. Cordier, C.; Pozo, M.J.; Barea, J.M.; Gianinazzi, S.; Gianinazzi-Pearson, V. Cell defense responses associated with localized and systemic resistance to Phytophthora parasitica induced in tomato by an arbuscular mycorrhizal fungus. Mol. Plant-Microbe Interact. 1998, 11, 1017-1028. [CrossRef] 